\title{
Floral development of Condylocarpon isthmicum (Apocynaceae)
}

\begin{tabular}{|r|l|}
\hline Journal: & Botany \\
\hline Manuscript ID & cjb-2015-0081.R1 \\
\hline Manuscript Type: & Article \\
\hline Date Submitted by the Author: & 16-Aug-2015 \\
\hline Complete List of Authors: & $\begin{array}{l}\text { Morokawa, Rosemeri; Unicamp, Biologia Vegetal } \\
\text { Mayer, Juliana; Unicamp, } \\
\text { Simões, Andre; Unicamp, } \\
\text { Kinoshita, Luiza; Unicamp, }\end{array}$ \\
\hline Keyword: & anatomy, colleter, histochemistry, nectary, obturator \\
\hline
\end{tabular}

\section{SCHOLARONE ${ }^{\text {m }}$}

Manuscripts 
Floral development of Condylocarpon isthmicum (Apocynaceae)

Rosemeri Morokawa, Juliana Lischka Sampaio Mayer, André Olmos Simões and Luiza Sumiko Kinoshita

R. Morokawa, Post-Graduate Program in Plant Biology, Institute of Biology, State University of Campinas, P.O. Box 6109, 13083-970, Campinas, São Paulo, Brazil, rmorokawa@gmail.com.

J.L.S. Mayer. Department of Plant Biology, Institute of Biology, State University of Campinas, P.O. Box 6109, 13083-970, Campinas, São Paulo, Brazil, mjimayer@yahoo.com.br.

A.O. Simões, Department of Plant Biology, Institute of Biology, State University of Campinas, P.O. Box 6109, 13083-970, Campinas, São Paulo, Brazil, aosimoes@unicamp.br.

L.S. Kinoshita, Department of Plant Biology, Institute of Biology, State University of Campinas, P.O. Box 6109, 13083-970, Campinas, São Paulo, Brazil, luizakin@unicamp.br.

Corresponding author: Rosemeri Morokawa (email: rmorokawa@gmail.com). 
Abstract

Apocynaceae is one of the largest families of angiosperms. Its representatives have flowers with relatively simple morphology, ranging from anthers free from the style head to more complex flowers in which the anthers are postgenitally united with the style head, forming a gynostegium, and those with a style head that is vertically differentiated into distinct functional regions. The aim of this study is to understand the morphology and secretory structures of Condylocarpon isthmicum at different stages of development. This species, which is in the family Apocynaceae, has morphologically simple flowers. Flowers at four different stages of development were collected and processed for anatomical and histochemical analysis; floral anatomy was examined using light and scanning electron microscopy. The simplicity of the C. isthmicum flower morphology was contrasted with the complexity observed in the secretory structures at different stages of flower development. Four secretory structures were identified in this species: colleters, style head epidermal cells, nectariferous tissue, and an obturator. The colleters were observed in the bracts and bracteoles of the young inflorescences. The style head began the secretory phase in the pre-anthetic stage and remained in this phase until anthesis. The nectariferous tissue was secreted during anthesis, and the obturator was present only in post-anthetic flowers. We identified a nectary in the wall of the ovary, and we verified and described a new structure in the Apocynaceae, the obturator.

Keywords: anatomy, colleter, histochemistry, nectary, obturator. 


\section{Introduction}

Apocynaceae is one of the largest families of angiosperms, with 360 genera (Endress et al. 2014) and approximately 5000 species (Meve 2002; Endress 2004). Five subfamilies are currently recognized: Rauvolfioideae, Apocynoideae, Periplocoideae, Secamonoideae and Asclepiadoideae (Endress and Bruyns 2000; Endress et al. 2014). Rauvolfioideae species have flowers with corolla usually salverform, anthers free from the style head and never forming a gynostegium, often unspecialized but modified in Tabernaemontaneae with large lignified guide rails, style head usually undifferentiated, entirely receptive or differentiated into a basal collar and/or upper crest, and fruits and seeds with a remarkable variety of forms (Endress \& Bruyns 2000; Simões et al. 2007). In contrast to Rauvolfioideae, species from the other four subfamilies have flowers with anthers always postgenitally united to the style head, forming a gynostegium; the style head is vertically differentiated into functional areas; the fruit is dry follicle and the seed is comose, wind-dispersed, with few exceptions.

Despite being one of the most derived tribes of Rauvolfioideae (Potgieter and Albert 2001; Sennblad and Bremer 2002; Endress et al. 2007b; Simões et al. 2007), Alyxieae is characterized by flowers with simple morphology. The style head is cylindrical to globose, without a basal collar, and is entirely covered with a homogeneous secretory epidermis; the anthers are not lignified and are completely fertile. This combination of characters is also present in species from the different tribes of Rauvolfioideae, such as Aspidospermeae, Willughbeieae, Melodineae, Carisseae, and Tabernaemontaneae (Endress and Bruyns 2000; Endress et al. 2007a; Simões et al. 2007). Condylocarpon is the only genera of Alyxieae with Neotropical distribution; it has seven species that are distributed primarily in northern Brazil and Guyana. It is commonly found in riparian forests (Fallen 1983a); Condylocarpon isthmicum (Vell.) A. DC. is widely distributed from northeastern Brazil to northern Argentina.

There is uncertainty regarding the presence of a nectary in Condylocarpon, as reported by Fallen (1983a)

in a taxonomic revision of the genus. In Apocynaceae, the nectary may be inconspicuous and the nectar appears to be secreted from the ovary wall (Fallen 1986) or is absent (Haber 1984). Typically, nectaries in Apocynaceae form a conspicuous ring that encircles the ovary, but nectaries with a receptacular or androecial origin have also been reported (Bernardello 2007).

Most studies examining floral anatomy and histochemistry in Apocynaceae have focused on specific organs, such as colleters (Appezzato-da-Glória and Estelita 2000; Rio et al. 2002; Simões et al. 2006; Martins 2012; 
Canaveze and Machado 2015) and laticifers (Appezzato-da-Glória and Estelita 1997; Sachetti et al. 1999; Serpe et al. 2001; Demarco et al. 2006; Lopes et al. 2009). The floral anatomy of several species of Apocynaceae has been documented in studies examining flower vascularization in representatives of various tribes of Apocynaceae s. str. (Woodson and Moore 1938), floral anatomy descriptions of representatives of Rauvolfioideae, Periplocoideae and Asclepiadoideae (Fallen, 1986; Rao and Ganguli 1961, 1963; Sarwat 1962), floral structure and reproductive biology of Aspidosperma quebracho-blanco Schltdl. (Lin and Bernardello 1999), and floral structure related to function in Morrenia (Wiemer et al. 2012) and Periploca species (Heneidak and Naidoo 2015). Nevertheless, most studies were based entirely on anthetic, fully developed flowers, and few have examined flowers at different developmental stages, for example, the study on the ontogeny of carpels in Catharanthus roseus (Walker 1975), the morphology and evolution of the corolla and corona in Apocynaceae (Kunze 2005), and the morphogenesis and histochemistry of pollinarium in species of Asclepiadeae (Demarco 2014).

The objective of this study was to analyze the anatomy and histochemistry of Condylocarpon isthmicum flowers at different stages of development to elucidate the floral structure and development of a species with apparently simple morphology, with an emphasis on secretory structures.

\section{Materials and methods}

\section{Botanical material}

Inflorescences at various stages of development were collected from three different locations in southeastern Brazil: Serra da Canastra National Park, Minas Gerais State, 11/X/2007, R. Morokawa et al. 100; Grota Funda Municipal Reserve, Atibaia, São Paulo State, 16/X/2007, R. Morokawa et al. 118; and Serra do Mar State Park, Picinguaba, Ubatuba, São Paulo State, XI/2005, I. Koch et al. The voucher specimens were deposited at the UEC herbarium (University of Campinas, Brazil). The samples were separated into four categories according to the following developmental stages: flower bud, pre-anthetic flower, anthetic flower, and post-anthetic flower. At the floral bud stage, flowers have a length of 2.0-2.5 mm and closed corolla lobes, whereas flowers at the pre-anthetic stage have a length of 4.0-4.5 mm and closed corolla lobes. Flowers at the anthetic stage have a length of 3.0-3.5 mm and open corolla lobes, and post-anthetic flowers have a fallen corolla and only the gynoecium is present. We also isolated the bracts of young inflorescences to analyze the colleters. 
Light microscopy

Samples were fixed in FAA (formalin, acetic acid, and 50\% alcohol; 1:1:18 v/v) for $24 \mathrm{~h}$ under vacuum and stored in 70\% ethanol (Johansen 1940). Subsequently, twenty flowers of each stage were dehydrated with a tertbutyl alcohol (TBA) series (Johansen 1940). A 3/4 volume of solid Histosec ${ }^{\circledR}$ was added to the samples in 100\% TBA, and maintained at $58^{\circ} \mathrm{C}$. Histosec ${ }^{\circledR}$ was replaced 3 times, once every $12 \mathrm{~h}$. The samples were placed in molds to solidify, and serial sections (10 $\mu \mathrm{m}$ thick) were sliced with a rotary microtome (Leica $\left.{ }^{\circledR}\right)$. Cross and longitudinal sections were stained with Astra Blue 1\% and alcoholic Safranin 1\% (Gerlach 1969) and mounted in Entellan ${ }^{\circledR}$ synthetic resin (Merck, Darmstadt, Germany). Photomicrographs were taken using an Olympus BX 51 photomicroscope equipped with an Olympus DP71 camera. The pictures were arranged in plates using CorelDRAW X3 version 13 (Corel Inc., Mountain View, CA, USA).

\section{Histochemistry}

The chemical composition of the substances found in the secretory cells and the secretions of the colleters was determined using the following histochemical tests: periodic acid-Schiff's (PAS) reaction for the 1, 2-glycol groups present in the polysaccharides (McManus 1948); 5\% tannic acid-3\% ferric chloride and methylene blue for the mucilage (Johansen 1940, Pizzolato and Lillie 1973); Aniline blue black (Fisher 1968) to identify proteins; Lugol's iodine solution for starch (Jensen 1962); 10\% ferric chloride for phenolic compounds (Johansen 1940); Wagner's reagent for alkaloids (Wagner et al. 1984); Nile blue (Cain 1947) to identify aliphatic compounds; and aniline blue for the callose (Currier and Strugger 1956). The respective controls were performed according to the protocol.

Scanning electron microscopy (SEM)

Twenty flowers at various stages were dehydrated in a graded ethanol series and critical point-dried using $\mathrm{CO}_{2}$ as a transitional fluid (Horridge and Tamm 1969). These samples were attached to aluminum stubs, coated with gold $(30-40 \mathrm{~nm})$ and examined under an LEO VP 435 scanning electron microscope at $10 \mathrm{kV}$. The images were edited to optimize brightness and contrast using CorelDRAW X3 version 13 (Corel Inc., Mountain View, CA, USA). 


\section{Results}

Morphology and histochemistry

The results from the histochemical tests are summarized in Table 1 . The secretory structures of $C$. isthmicum at inflorescence and different stages of floral development are presented below.

\section{Inflorescence}

The inflorescences are many-flowered terminal thyrsi with a congested growth form that appear to be cymes or even umbels. The bracts and bracteoles have 2-3 standard colleters at the base of the adaxial surface. A viscous substance can be observed on the apical portions of the colleters (Figs. 1A, 1B, asterisk). The apices of the bracts and bracteoles also have colleters that are formed by a unistratified secretory epidermis on the adaxial face or on both surfaces in the apical portion (Fig. 1C). The observed colleters are formed by a central axis of nonsecretory parenchyma cells surrounded by a secretory unistratified epidermis. The cells from this secretory epidermis are elongated and arranged in a palisade, covered by a thin cuticle, and have a dense cytoplasm (Fig. 1D). The secretions released by the epidermal cells were deposited under the cuticle, inducing its distention and forming a subcuticular space (Figs. 1C, 1F-1H, arrows). Polysaccharides (Figs. 1E, 1F), mucilage (Figs. 1G, 1H) and lipophilic substances (Figs. 1C, 1I-1J) can be observed inside the secretory cells and also in the extracellular space next to the colleters. Proteins can also be observed, but only within the protoplast of the secretory cells (Fig. 1D).

\section{Flower bud}

Idioblasts with phenolic compounds are distributed in the sepals and corolla, primarily at the proximal region of the corolla tube opposite the calyx lobes and on the abaxial side of the corolla lobes (Figs. 2A-2D). The calyx has five lobes with quincuncial aestivation (Fig. 2C), and without colleters. The abaxial epidermis of the calyx has stomata and unicellular tectory trichomes, which are absent on the adaxial side. The androecium has five epipetalous stamens (Fig. 2C). The anthers are positioned at the level of the style head, close to the flower base (Fig. 2A). The gynoecium is bicarpelar and hemisyncarpic. The carpels are free from each other for the most part but are united at the ovary base and at the distal portion of the style to form the style head (Fig. 2A). Each carpel has two rows of three ovules (Fig. 2D). The ovary is superior, the style inconspicuous and the style head globose to 
subglobose. The style head is 2.0 to $2.5 \mathrm{~mm}$ in length and consists of a main body and two free apical appendages with cuboids epidermal cells.

Pre-anthesis

The upper portion of the corolla tube is greatly enlarged compared with the earlier examined stage, with a reduced tube diameter (Fig. 3A). The anthers are positioned above the style head (Fig. 3A). The anthers are oval, completely fertile and tetrasporangiate, with each theca bearing two pollen sacs separated by a septum. During this stage, pollen grains are occasionally released in tetrads through longitudinal slits of the thecae. The unicellular corolline trichomes are located below the point of insertion of the stamen at the middle of the corolla tube and are organized into five protrusions, each with an angle of approximately $90^{\circ}$ to the corolla tube and directed towards the style head (Figs. 3A-3B). The trichomes located between these protrusions, however, form an angle of approximately $45^{\circ}$ to the corolla tube and are directed towards the flower base. The style head reaches $4 \mathrm{~mm}$ in length, with epidermal cells developed in trichomes, and it becomes fully developed (Fig. 3C). These trichomes are longer at the base of the main body of the style and gradually shorten toward its tip (Fig. 3E). The trichomes start secreting a thin layer of secretion that can be observed around and between the trichomes. The cells of the style head and the surrounding exudate reacted positively to the tests for polysaccharides (Fig. 3C) and mucilage (Fig. 3D). The placental epidermal cells are differentiated in the pre-anthetic flowers compared with those in the flower buds (Fig. $3 \mathrm{~F})$.

Anthesis

The corolla is fully expanded, yellow or orange, salverform with sinistrorse aestivation (Figs, 4A-4B); the lobes are oblique with a long caudate ending (Fig. 4A). The adaxial epidermis of the lobes and corolla is papillose, with an ornamented cuticle forming conspicuous ridges (Figs. 4C-4D).

The style reaches its maximum length (approximately $130 \mathrm{~mm}$ ). The style head is covered with a thick layer of secretion (Figs. 4E-4F). All pollen grains have been released in tetrads through longitudinal slits of the thecae. The secretion produced by the trichomes of the style head hold the tetrad pollen grains together above the style head (Fig. 4G). The growth of the pollen tubes at both the apex and lateral region of the style head were confirmed using aniline blue staining (Fig. 6F). 
The cells at the base of the ovary close to the epidermis differ from the adjacent parenchyma cells by having a more compact arrangement, smaller size, dense cytoplasm and conspicuous nuclei. Several stomata can be observed at the ovary base; SEM images provide evidence of the secretion released from this region (Figs. 4H, 4I). Histochemical tests show that cells at the ovary base close to the epidermis contain polysaccharides (Fig. 5A), starch (Fig. 5B), and proteins (Fig. 5C). The histochemical composition indicates the presence of nectariferous tissue with three to four cell layers.

The placental epidermal cells are elongated and juxtaposed, with thin walls and dense cytoplasmic contents (Figs. 5D-5E). The dense cytoplasm contains polysaccharides, mucilage, starch (Fig. 5F), and proteins (Fig. $5 \mathrm{G})$.

Post-anthesis

The corolla has fallen, and only the gynoecium and calyx is present in this stage. The base of the style head starts to shrivel (Fig. 6E) and abscise (Fig. 6C), the secretions are scarce, and the tetrad pollen grain is deflated (Fig. 6E). Secretion within the ovary locule is observed only in this stage (Figs. 6A-6B). The placental epidermal cells extend from the base to the apex of the ovary locule (Fig. 6C) and near the micropyle. These cells are characterized here as a placentary obturator due to their position and function. In post-anthetic flowers, the secretion tested positive for total polysaccharides (Fig. 6D) and mucilage. Starch granules were not observed in the exudate or within the cells of the placentary obturator.

\section{Discussion}

The structural analysis of the flowers of C. isthmicum revealed a simple morphology, with fully fertile anthers positioned above an undifferentiated style head. This structural pattern is known for several representatives of most tribes of Rauvolfioideae and differs from the pattern reported for other subfamilies of Apocynaceae in which the anthers are partially fertile and adnate to the style head, forming a gynostegium, and the style head is vertically differentiated into functional areas (Endress and Bruyns 2000). The simplicity of the C. isthmicum flowers is similar to that reported for other genera of Alyxeae (Fallen 1986, Middleton 2000, Leeuwenberg 2002, Endress et al. 2007b). The complexity observed in C. isthmicum is in the secretory activity of each structure at different stages of 
floral development. The main secretory structures observed in C. isthmicum flowers were the style head epidermis, nectary, and placentary obturator. Another secretory structure very common in Apocynaceae is the colleter, which is present only at inflorescence.

Colleters, which were present in the bracts in inflorescence development, secreted a sticky substance that covered and protected the flower buds. The secretion produced by the colleters was deposited on the developing organs, which might protect them against dehydration, as described by Mayer et al. (2013) for the colleters of Coffea spp. flowers. We classified the colleters observed on the surface of adaxial bracts of C. isthmicum as 'standard type' (S), following Lersten $(1974 a, b)$. The chemical composition of the exudate, determined by general histochemical tests, was complex and heterogeneous and contained a mixture of polysaccharides, mucilage and lipophilic substances. There are few records of colleters in the bracts and bracteoles of Apocynaceae (Thomas and Dave 1989a, b, Thomas et al. 1989). This is because most of the authors (e.g., Woodson and Moore 1938, Rao and Ganguli 1963, Fallen 1986, Thomas and Dave 1990, 1991) examined only the flowers and not the inflorescences.

Other types of colleters were found at the apices of the bracts and bracteoles of C. isthmicum, which were formed by a single layer of secretory epidermis on the adaxial face or on both surfaces in the apical portion of the structure. There are no classification or histochemical studies on this type of colleter in the literature, and only brief morphological descriptions are found for species such as Plumeria, for which Woodson (1938) described the epidermal cells of the apex of the calyx as elongated, with histological and cytological characteristics of secretory tissues. The other species most likely have colleters at the apices of the bracts, bracteoles or calyx, but they have remained unnoticed because they are small and enter senescence after a secretory phase.

Calycine colleters are present in most genera of Apocynaceae s.1. (Endress and Bruyns 2000, Simões et al. 2006) but are absent in C. isthmicum, an observation also recorded by Fallen (1983a, 1986), Kinoshita (2005) and Endress et al. (2007b). Although Thomas (1991) reported that calycine colleters were observed in Condylocarpon, based on Fallen (1983b), we suspect that he misunderstood this observation because there is no mention of these structures in Fallen (1983b).

Most tribes of Rauvolfioideae, such as Aspidospermeae (Fallen 1986, Simões et al. 2007), Hunterieae (Fallen 1986), Carisseae (Fallen 1986, Koch et al. 2002, Simões et al. 2007), Willughbeieae, Alstonieae and Tabernaemontaneae (Endress et al. 2007b, Simões et al. 2007), have species with morphologically simple style heads such as the one found in C. isthmicum. The primary difference among the species that have the simple style head is 
the location of the secretory region. In C. isthmicum, the style head is uniformly receptive and both apical appendages and the main body regions release secretions; this pattern is also observed in several species of Aspidospermeae (Fallen 1986, Simões et al. 2007) and in most species of Alyxieae (Endress et al. 2007b). In the other groups, such as Hunterieae, Melodineae, Tabernaemontaneae, and Willughbeieae, only the main body of the style head releases a secretion, as the apical appendages are not secretory (Fallen 1986). The activity of the style head of $C$. isthmicum is initiated in the pre-anthesis stage and remains until the anthesic stage.

Alyxeae pollen grains are usually in monads with 2-5 apertures, with the exception of C. isthmicum, which shows peculiar tetrads and inaperturate pollen (Van der Ham et al. 2001). In pre-anthesis and anthesis, we observed that the pollen grains are released in tetrads and remain together in tetrad formation above the style head surrounded by the secretions of the style head epidermis.

In a taxonomic revision of Condylocarpon, Fallen (1983a) reported an uncertainty with respect to the presence or absence of a nectary in the genus. Although the presence of nectar in this species is difficult to observe because of the reduced size of the flower and the small amount of nectar produced, we confirmed, based on anatomical and histochemical evidence, that $C$. isthmicum has an inconspicuous nectary and that nectar is released by the stomata in the ovary wall during anthesis. The species Aspidosperma quebracho-blanco has an inconspicuous annular nectary located at the base of the ovary (Lin and Bernardello 1999), which is very similar to the nectary of $C$. isthmicum; however, it was characterized as nonfunctional because of the absence of nectar. When present, nectaries are commonly found as a conspicuous ring or lobes at the ovary base in species of subfamilies Rauvolfioideae and Apocynoideae. In Asclepiadoideae and Secamonoideae, nectar is usually produced by staminal cells and stored within the corona, from where it is accessible for the pollinators.

Floral nectar is a resource accessible to pollinators and is an important source of food in the diet of various insects (Faegri and van der Pijl 1980, Baker and Baker 1990). The cells of nectariferous tissue in C. isthmicum are small and have a dense cytoplasm, otherwise the subnectariferous parenchyma have large cells and a less dense cytoplasm, and vascular bundles. These characteristics are consistent with the description of subnectariferous parenchyma proposed by Nepi (2007). On the surface of the nectary of $C$. isthmicum, stomata with open pores were consistently observed. According to Fahn (1979), these pores can be interpreted as modified stomata with guard cells that lost their ability to move because of the reduced substomatic space and the proximity of nectariferous 
parenchyma cells (Davis and Gunning 1992, 1993). The presence of fungal hyphae in the regions of the nectary of $C$. isthmicum (personal observation) could indicate the presence of nectar sugar (Canto and Herrera 2012).

The placentary obturator is a type of secretory tissue formed by ovarian epidermal cells. These cells are elongated with thin walls, dense cytoplasm and conspicuous nuclei (Shamrov 2002). The cells of the internal epidermis of the ovary of C. isthmicum had these characteristics and during the secretory phase, which began at flower post-anthesis, released a secretion composed of polysaccharides and mucilage. Placentary obturators have been described in several unrelated angiosperm families, including Liliaceae (Tilton and Horner 1980); Leguminosae (Tilton et al. 1984); Rosaceae (Arbeloa and Herrero 1987, Rodrigo and Herrero 1998); Rutaceae (Zhou et al. 2004); Magnoliaceae (Umeda et al. 1994); Rubiaceae (Block 1995); and Phyllanthaceae (Zhang et al. 2012). However, the obturator has also been described in related families of Malpighiales. Further, Endress et al. (2013) suggested that the presence of an obturator associated with other gynoecium and ovule features could support suprafamilial clades within Malpighiales. In Prunus armeniaca L. (Rosaceae), the synthesis and release of secretions by the cells of the obturator is a prerequisite for pollen tube penetration into the egg, and the failure of this synthesis leads to chaotic pollen tube growth and a reduced fertilization rate (Rodrigo and Herrero 1998). The presence of starch grains in the obturator cells of $C$. isthmicum during the pre-secretory phase was also observed in $P$. armeniaca (Rodrigo and Herrero 1998) and Prunus persica (L.) Batsch (Arbeloa and Herrero 1987); these authors considered that these starch reserves were necessary for the production of the secretions.

In a study on the structure and histochemistry of the pollen tube pathway in Asclepias exaltata L. (Apocynaceae), Sage and Williams (1995) identified a secretory function for the placental epithelium, and the extracellular secretions stained positive for proteins and insoluble carbohydrates. Despite these observations that the epithelium could be an obturator, the authors did not designate the tissue as an obturator. In his Master's thesis, Demarco (2005) suggested the presence of an obturator in Aspidosperma australe, and later in his Doctoral thesis (Demarco 2008), he structurally and histochemically characterized the obturator in four species of Asclepiadeae. Our study is the first to recognize the presence of an obturator in the family Apocynaceae.

In conclusion, Condylocarpon isthmicum have simple flowers at a morphological level, similar to other groups of Apocynaceae. However, the studies on ontogeny revealed an array of secretory phases in this species. The style head begins to release secretions during the pre-anthesis stage and remains active until anthesis. The secretion of the style head is copious and covers the entire style head with a thick layer of secretion, which acts as a pollen 
trap. The nectar is released by the stomata in anthetic flowers, and the obturator secretions occur only in postanthetic flowers. In this study, the presence of the nectary in the wall of the ovary is confirmed, and a new structure of the ovary, the obturator, is formally described for the first time in Apocynaceae.

\section{Acknowledgments}

The authors thank the National Council for Scientific and Technological Development (CNPq) for the financial support (process: 473797/2007-0).

\section{Conflicts of Interest Statement}

None declared.

\section{References}

Appezzato-da-Gloria, B., and Estelita, M.E.M. 1997. Laticifer systems in Mandevilla illustris and M. velutina (Apocynaceae). Acta Soc. Bot. Pol. 66(3-4):301-306. doi: 10.5586/asbp.1997.035

Appezzato-da-Glória, B., and Estelita, M.E.M. 2000. Development, structure and distribution of colleters in Mandevilla illustris and M. velutina (Apocynaceae). Rev. Bras. Bot. 23(2): 113-120. doi: 10.1590/S010084042000000200001

Arbeloa, A., and Herrero, M. 1987. The significance of the obturator in the control of pollen tube entry into the ovary in peach (Prunus persica). Ann. Bot. 60(6): 681-685.

Baker, H.G., and Baker, I. 1990. The predictive value of nectar chemistry to the recognition of pollinator type. Israel J. Bot. 39: 157-166. doi: 10.1080/0021213X.1990.10677140.

Bernardello, G. 2007. A systematic survey of floral nectaries. In Nectaries and nectar. Edited by S.W. Nicolson, M. Nepi, E. Pacini. Springer, Dordrecht. pp. 19-128.

Block, P. 1995. Ovary, seed and fruit of Rutidea (Rubiaceae, Pavetteae). Plant Syst. Evol. 196(1-2): 1-17. doi: 10.1007/BF00985332

Cain, A.J. 1947. The use of Nile Blue in the examination of lipids. Q. J. Microsc. Sci. 88: 383-392.

Canaveze, Y., and Machado, S.R. 2015. Leaf colleters in Tabernaemontana catharinensis (Apocynaceae, Rauvolfioideae): structure, ontogenesis, and cellular secretion. Botany 93: 287-296. 
Canto, A., and Herrera, C.M. 2012. Micro-organisms behind the pollination scenes: microbial imprint on floral nectar sugar variation in a tropical plant community. Ann. Bot. 110(6): 1173-1183. doi: $10.1093 / \mathrm{aob} / \operatorname{mcs} 183$.

Currier, H.B., and Strugger, S. 1956. Aniline blue and fluorescence microscopy of callose in bulb scales of Allium cepa L. Protoplasma 45(4): 552-559.

Davis, A.R., and Gunning, B.E.S. 1992. The modified stomata of the floral nectary of Vicia faba L. 1. Development, anatomy and ultrastructure. Protoplasma 166(3-4): 134-152.

Davis, A.R., and Gunning, B.E.S. 1993. The modified stomata of the floral nectary of Vicia faba L. 3. Physiological aspects, including comparisons with foliar stomata. Bot. Acta. 106(3): 241-253. doi: 10.1111/j.14388677.1993.tb00747.x.

Demarco, D. 2005. Estruturas secretoras florais e coleteres foliares em espécies de cerrado de Aspidosperma Mart. e Blepharodon Decne. (Apocynaceae s.1.). M.Sc. thesis, Department of Plant Biology, University of Campinas, Campinas, Brazil. http://www.bibliotecadigital.unicamp.br/document/?code=vtls000350078\&opt=4

Demarco, D. 2008. Glândulas de órgãos vegetativos aéreos e florais de espécies de Asclepiadeae (R. Br) Duby (Asclepiadoideae, Apocynaceae) de Mata Atlântica do estado de São Paulo. Ph.D. thesis, Department of Plant Biology, University of Campinas, Campinas, Brazil. http://www.bibliotecadigital.unicamp.br/document/?code=000434859

Demarco, D. 2014. Secretory tissues and the morphogenesis and histochemistry of pollinarium in flowers of Asclepiadeae (Apocynaceae). Int. J. Plant Sci. 175(9): 1042-1053.

Demarco, D., Kinoshita, L.S., and Castro, M.M. 2006. Laticíferos articulados anastamosados novos registros para Apocynaceae. Rev. Bras. Bot. 29(1): 133-144.

Endress, M.E., and Bruyns, P.V. 2000. A revised classification of the Apocynaceae s.1. Bot. Rev. 66(1): 1-56. doi: 10.1007/BF02857781.

Endress, M.E. 2004. Apocynaceae: brown and now. Telopea 10(2): 525-541.

Endress, M.E., Liede-Schumann, S., and Meve, U. 2007a. Advances in Apocynaceae: the enlightenment, an introduction. Ann. Missouri Bot. Gard. 94(2): 259-267. doi: http://dx.doi.org/10.3417/00266493(2007)94[259:AIATEA]2.0.CO;2. 
Endress, M.E., Ham, R.W.J.M., Nilsson, S., Civeyrel, L., Chase, M.W., Sennblad, B., Potgieter, K., Joseph, J., Powell, M., Lorence, D., Zimmerman, Y.M., and Albert, A.A. 2007b. A phylogenetic analysis of Alyxieae (Apocynaceae) based on rbcL, matK, trnL intron, trnL-F spacer sequences, and morphological characters. Ann. Missouri Bot. Gard. 94(1): 1-35. doi: 10.3417/0026-6493(2007)94\%5B1:APAOAA\%5D2.0.CO;2.

Endress, M.E., Liede-Schumann, S., and Meve, U. 2014. An updated classification for Apocynaceae. Phytotaxa 159(3): 175-194. doi: http://dx.doi.org/10.11646/phytotaxa.159.3.2.

Endress, P.K., Davis, C.C., and Matthews, M.L. 2013. Advances in the floral structural characterization of the major subclades of Malpighiales, one of the largest orders of flowering plants. Ann. Bot. 111: 969-985. doi:10.1093/aob/mct056

Faegri, K., and van Der Pijl, L. 1980. The principles of pollination ecology. Pergamon Press, New York.

Fahn, A. 1979. Secretory tissues in plants. New York, NY: Academic Press.

Fallen, M.E. 1983a. A taxonomic revision of Condylocarpon (Apocynaceae). Ann. Missouri Bot. Gard. 70(1): 149169.

Fallen, M.E. 1983b. A systematic revision of Anechites (Apocynaceae). Brittonia 35(3): 222-231. doi: $10.2307 / 2806018$.

Fallen, M.E. 1986. Floral structure in the Apocynaceae: morphological, functional, and evolutionary aspects. Bot. Jahrb. Syst. Pflanzengesch. Pflanzengeogr. 106: 245-286.

Fisher, D.B. 1968. Protein staining of ribboned epon sections for light microscopy. Histochemie 16(1): 92-96.

Gerlach, D. 1969. Botanische Mikrotechnik: Eine Einführung. Sttutgart: Georg Thieme Verlag, Stuttgart.

Haber W.A. 1984. Pollination by deceit in a mass-flowering tropical tree Plumeria rubra L. (Apocynaceae). Biotropica 16(4): 269-275.

Heneidak, S., and Naidoo, Y. 2015. Floral function in relation to floral structure in two Periploca species (Periplocoideae) Apocynaceae. Turk. J. Bot. 39: 673-680.

Horridge, G.A., and Tamm, S.L. 1969. Critical point drying for scanning electron microscopy study of ciliary motion. Science 163(3869): 817-818. doi: 10.1126/science.163.3869.817.

Jensen, W.A. 1962. Botanical histochemistry: principles and practice. WH Freeman, San Francisco.

Johansen, D.A. 1940. Plant microtechnique. New York: McGraw-Hill. 
Kinoshita, L.S. 2005. Condylocarpon Desf. In Flora Fanerogâmica do Estado de São Paulo. Edited by M.G.L. Wanderley, G.J. Shepherd, T.S. Melhem, S.E. Martins, M. Kirizawa, A.M. Giulietti. Fapesp, RiMa. São Paulo. pp. 47-48.

Koch, I., Bittrich, V., and Kinoshita, L.S. 2002. Reproductive biology and functional aspects of the floral morphology of Rauvolfia sellowii Müll. Arg. (Apocynaceae; Rauvolfioideae) — a report of dioecy in Apocynaceae. Bot. Jahrb. Syst. Pflanzengesch. Pflanzengeogr. 124(1): 83-104. doi: 10.1127/0006$8152 / 2002 / 0124-0083$.

Kunze, H. 2005. Morphology and evolution of the corolla and corona in the Apocynaceae s.1. Bot. Jahrb. Syst. Pflanzengesch. Pflanzengeogr. 126: 347-383.

Leeuwenberg, A.J.M. 2002. Series of revisions of Apocynaceae LII: Chilocarpus. Syst. Geogr. Plants 72: $127-166$.

Lersten, N.R. 1974a. Morphology and distribution of colleters and crystals in relation to the taxonomy and bacterial leaf nodule symbiosis of Psychotria (Rubiaceae). Am. J. Bot. 61(9): 973-981.

Lersten, N.R. 1974b. Colleter morphology in Pavetta, Neorosea and Tricalysia (Rubiaceae) and its relationship to the bacterial leaf nodule symbiosis. Bot. J. Linn. Soc. 69(2): 125-136. doi: 10.1111/j.10958339.1974.tb01620.x.

Lin, S., and Bernardello, G. 1999. Flower structure and reproductive biology in Aspidosperma quebracho-blanco (Apocynaceae), a tree pollinated by deceit. Int. J. Plant Sci. 160(5): 869-878. doi: 10.1086/314187.

Lopes, K.L.B., Thadeo, M., Azevedo, A.A., Soares A.A., and Meira, R.M.S.A. 2009. Articulated laticifers in the vegetative organs of Mandevilla atroviolaceae (Apocynaceae, Apocynoideae). Botany 87: 201-209.

Martins, F.M. 2012. Leaf and calycine colleters in Odontadenia lutea (Apocynaceae-Apocynoideae-Odontadenieae): Their structure and histochemistry. Rev. Bras. Bot. 35: 59-69.

Mayer, J.L.S., Carmello-Guerreiro, S.M., and Mazzafera, P. 2013. A functional role for the colleters of coffee flowers. AoB Plants 5. doi: 10.1093/aobpla/plt029.

Meve, U. 2002. Species numbers and progress in asclepiad taxonomy. Kew Bull. 57(2): 459-464.

McManus, J.F.A. 1948. Histological and histochemical uses of periodic acid. Stain Technol. 23(3): 99-108.

Middleton, D.J. 2000. Revison of Alyxia, part 1: Asia and Malesia. Blumea 45(1): 1-146.

Nepi, M. 2007. Nectary structure and ultrastructure. In Nectaries and nectar. Edited by S.W. Nicolson, M. Nepi, E. Pacini. Dordrecht, Springer. pp. 129-166. 
Pizzolato, P., and Lillie, R.D. 1973. Mayer's tannick acid-ferric chloride stain for mucins. J. Histochem. Cytochem. 21(1): 56-64. doi: 10.1177/21.1.56.

Potgieter, K., Albert, V.A. 2001. Phylogenetic relationships within Apocynaceae s. l. based on $\operatorname{trn} \mathrm{L}$ intron and $\operatorname{trn} \mathrm{L}-$ F spacer sequences and propagule characters. Ann. Missouri Bot. Gard. 88(4): 523-549.

Rao, V.S., and Ganguli, A. 1963. The floral anatomy of some Asclepiadaceae. Proc. Ind. Acad. Sci., B 57(1): 15-44.

Rio, M.C.S., Castro, M.C., and Kinoshita, L.S. 2002. Distribuição e caracterização anatômica dos coléteres foliares de Prestonia coalita (Vell.) Woodson (Apocynaceae). Rev. Bras. Bot. 25(3): 339-349.

Rodrigo, J., and Herrero, M. 1998. Influence of intraovular reserves on ovule fate in apricot (Prunus armenioca L.). Sex Plant Reprod. 11: 86-93.

Sacchetti, G., Ballero, M., Serafini, M., Romagnoli, C., Bruni, A., and Poli, F. 1999. Laticifer tissue distribution and alkaloid location in Vinca sardoa (Stearn) Pign. (Apocynaceae), an endemic plant of Sardinia (Italy). Phyton 39(2): 265-275.

Sage, T.L., and Williams, E.G. 1995. Structure, ultrastructure, and histochemistry of the pollen tube pathway in the milkweed Asclepias exaltata L. Sex. Plant Reprod. 8: 257-265. doi: 10.1007/BF00229381.

Sennblad, B., and Bremer, B. 2002. Classification of Apocynaceae s.l. according to a new approach combining Linnaean and phylogenetic taxonomy. Syst. Biol. 51(3): 389-409. doi: 10.1080/10635150290069869.

Serpe, M.D., Muir, A.J., and Keidek, A.M. 2001. Localization of cell wall polysaccharides in nonarticulated laticifers of Asclepias speciosa. Protoplasma, 216(3-4): 215-226. doi: 10.1007/BF02673873.

Shamrov, I.I. 2002. Obturator. In Embryology of flowering plants, terminology and concepts, volume 1: generative organs of flower. Edited by J.B. Batygina, J.B. Science Publishers, Enfield. pp. 128-130.

Simões, A.O., Castro, M.M., and Kinoshita, L.S. 2006. Calycine colleters of seven species of Apocynaceae (Apocynoideae) from Brazil. Bot. J. Linn. Soc. 152(3): 387-398. doi: 10.1111/j.1095-8339.2006.00572.x.

Simões, A.O., Livshultz, T., Conti, E., and Endress, M.E. 2007. Phylogeny and systematics of the Rauvolfioideae (Apocynaceae) based on molecular and morphological evidence. Ann. Missouri Bot. Gard. 94(2): 268297. doi: http://dx.doi.org/10.3417/0026-6493(2007)94[268:PASOTR]2.0.CO;2.

Tilton, V.R., and Horner, H.T., Jr. 1980. Stigma, style and obturator of Ornithogalum caudatum (Liliaceae) and their function in the reproductive process. Am. J. Bot. 67(7): 1113-1131. 
Tilton, V.R., Wilcox, L.W., Palmer, R.G., and Albertsen, M.C. 1984. Stigma, style, and obturator of soybean,

Glycine $\max (\mathrm{L}$.$) Merr. (Leguminosae) and their function in the reproductive process. Am. J. Bot.$ 71(5): 676-686.

Thomas, V. 1991. Structural, functional and phylogenetic aspects of the colleter. Ann. Bot. 68(4): 287-30.

Thomas, V., and Dave, Y. 1989a. Histochemistry and senescence of colleters of Allamanda cathartica (Apocynaceae). Ann. Bot. 64(2): 201-203.

Thomas, V., and Dave, Y. 1989b. Structure, origin, development and senescence of colleters in Nerium indicum Mill (N. odorum Soland., Apocynaceae). Korean J. Bot. 32(3): 163-172.

Thomas, V., and Dave, Y. 1990. Mode of secretion in the colleters of Alstonia scholaris (Apocynaceae). Phyton 30(2): 209-212.

Thomas, V. and Dave, Y. 1991. Comparative and phylogenetic significance of the colleters in the family Apocynaceae. Feddes Repert. 102(3-4): 177-182.

Thomas, V., Dave, Y., and Menon, A.R.S. 1989. Anatomy and histochemistry of colleters in Roupelia grata (Apocynaceae). Nord. J. Bot. 8(5): 493-496.

Umeda, A., Imaichi, R., and Kato, M. 1994. Ovular development and morphology of the outer integument of Magnolia grandiflora (Magnoliaceae). Am. J. Bot. 81(3): 361-367.

Van der Ham, R., Zimmermann, Y., Nilsson, S., and Igersheim, A. 2001. Pollen morphology and phyogeny of the Alyxieae (Apocynaceae). Grana 40(4-5): 169-191.

Wagner, H., Bladt, S., and Zgainski, E.M. 1984. Plant Drug Analysis - A Thin Layer Chromatography. Atlas; New York: Springer-Verlag.

Walker, D.B. 1975. Postgenital fusion in Catharanthus roseus (Apocynaceae). I. Light and scanning microscopic study of gynoecial ontogeny. Amer. J. Bot. 62: 457-467.

Wiemer, A.P., Sérsic, A.N., Marino, S., Simões, A.O., and Cocucci, A.A. 2012. Functional morphology and wasp pollination of two South American asclepiads (Asclepiadoideae-Apocynaceae). Ann. Bot. 109: 7793.

Woodson, R.E. 1938. Studies in the Apocynaceae VII: An evaluation of the genera Plumeria L. and Himatanthus Willd. Ann. Missouri Bot. Gard. 25(1): 189-224. 
Woodson, R.E., and Moore, J.A. 1938. The vascular anatomy and comparative morphology of apocynaceous flowers. Bull. Torrey Bot. Club 65(3): 135-165.

Zhang, Z., Meng, A., Li, J., Ye, Q., Wang, H., and Endress, P.K. 2012. Floral development of Phyllanthus chekiangensis (Phyllanthaceae), with special reference to androecium and gynoecium. Plant Syst. Evol. 298: 1229-1238. doi: 10.1007/s00606-012-0629-1.

Zhou, Q., Jin, X., and Fu, D. 2004. Developmental morphology of obturator and micropyle and pathway of pollen tube growth in ovary in Phellodendron amurense (Rutaceae). Act Bot. Sin. 46(12):1434-1442. 
Table 1. Histochemistry of secretory structures of the reproductive and vegetative organs of Condylocarpon isthmicum.

\begin{tabular}{|c|c|c|c|c|c|}
\hline \multirow[b]{2}{*}{ Metabolites } & \multirow[b]{2}{*}{ Staining procedures } & \multicolumn{4}{|c|}{ Reactivity } \\
\hline & & $\begin{array}{l}\text { Inflorescence } \\
\text { (colleters) }\end{array}$ & $\begin{array}{l}\text { Pre-anthesis } \\
\text { (Cells of the style head } \\
\text { and obturator) }\end{array}$ & $\begin{array}{l}\text { Anthesis } \\
\text { (Cells of the style head, } \\
\text { obturator and nectary) }\end{array}$ & $\begin{array}{l}\text { Post-anthesis } \\
\text { (Cells of the } \\
\text { obturator) }\end{array}$ \\
\hline Total polysaccharides & PAS reaction & $+(*)$ & $\begin{array}{l}+(\text { Cells of the style } \\
\text { head* and cells of the } \\
\text { obturator })\end{array}$ & $\begin{array}{l}+(\text { Cells of the style } \\
\text { head*, obturator*, and } \\
\text { nectary })\end{array}$ & $+(*)$ \\
\hline Mucilage & $\begin{array}{l}\text { Tannic acid-ferric } \\
\text { chloride }\end{array}$ & $+(*)$ & $\begin{array}{l}+(\text { Cells of the style } \\
\text { head*, and cells of the } \\
\text { obturator })\end{array}$ & $\begin{array}{l}+(\text { Cells of the style } \\
\text { head, obturator*) }\end{array}$ & $+(*)$ \\
\hline Aliphatic compounds & Nile blue & $+(*)$ & - & - & - \\
\hline Starch & Lugol's & - & $\begin{array}{l}+ \text { (Cells of the } \\
\text { obturator })\end{array}$ & + (Nectary) & - \\
\hline Phenolic compounds & $10 \%$ ferric chloride & - & - & - & - \\
\hline Total proteins & Aniline blue black & + & $\begin{array}{l}+ \text { (Cells of the } \\
\text { obturator })\end{array}$ & $\begin{array}{l}+ \text { (Nectary, cells of the } \\
\text { style head and, } \\
\text { obturator) }\end{array}$ & + \\
\hline Alkaloids & Reagent of Wagner & - & - & - & - \\
\hline
\end{tabular}

The positive $(+)$ and negative (-) signs indicate the presence and absence of a reaction.

* Positive signs in extracellular secretions. 
Fig. 1. Colleters of Condylocarpon isthmicum. A-B. SEM, colleters on the adaxial surface of bracts in a young inflorescence. C-J. Histochemical characterization of the exudate in the colleters. C. Nile blue. D. Aniline blue black. E-F. PAS reaction. G-H. Tannic acid-ferric chloride. I-J. Nile blue. Asterisk = extracellular secretion. Arrows = Colleters at the secretory stage; note the cuticle displacement and subcuticular space. br $=$ bracteole; ca $=$ central axis formed by nonsecretory parenchyma cells; $\mathrm{sp}=$ secretory palisade epidermis. Scale bars: A-F, H-J = $20 \mu \mathrm{m} ; \mathrm{G}=50$ $\mu \mathrm{m}$.

Fig. 2. Sections of the flower bud of Condylocarpon isthmicum. A. Longitudinal section. B-D. Cross sections; dotted lines indicate the position of the sections. an = anther; $\mathrm{ca}=$ calyx; $\mathrm{co}=$ corolla; $\mathrm{lc}=$ corolla lobes; $\mathrm{pe}=\mathrm{pedicel}$; ov $=$ ovary; re = receptacle; $\mathrm{sh}=$ style head. Scale bars $=200 \mu \mathrm{m}$.

Fig. 3. Pre-anthetic Condylocarpon isthmicum flower. A. Longitudinal section, anthers positioned above the style head. B. Cross section, detail of trichome. C-D. Histochemical characterization of the style head. C. PAS reaction. D. Tannic acid-ferric chloride; note the extracellular secretion $\left(^{*}\right)$. E. SEM, style head covered by secretory epidermis. F. Longitudinal section of ovary. asterisk = secretion; $a n=$ anther; $c o=$ corolla; $\mathrm{t}=$ trichomes; $\mathrm{sh}=$ style head; $\mathrm{sc}=$ secretory cell; $\mathrm{ob}=$ obturator; $\mathrm{mi}=$ micropyle. Scale bars: $\mathrm{A}=100 \mu \mathrm{m}$; and $\mathrm{B}-\mathrm{E}=20 \mu \mathrm{m}$.

Fig. 4. Anthetic Condylocarpon isthmicum flower. A-B. Frontal view. C. Detail of adaxial epidermis of the lobes of the corolla near the aperture. D. Detail of ornamented cuticle. E. Style head covered by secretion. F. Detail of style head secretory cells covered by secretion. G. Tetrad pollen grains on the style head secretory epidermis. H-I. Nectary at the base of the ovary. I. Detail of nectar-secreting stomata. asterisk $=$ secretion; an $=$ anther; $p g=$ tetrad pollen grain; $\mathrm{sc}=$ secretory cell; $\mathrm{st}=$ stomata. Scale bars: $\mathrm{A}=2 \mathrm{~mm} ; \mathrm{B}-\mathrm{C}, \mathrm{E}=100 \mu \mathrm{m} ; \mathrm{D}=10 \mu \mathrm{m} ;$ and F-I. $=20 \mu \mathrm{m}$.

Fig. 5. Anthetic Condylocarpon isthmicum flower. A-C. Longitudinal sections. Histochemical characterization of the nectary at the base of the ovary. A. PAS reaction. B. Lugol's. C. Aniline blue black. D-G. Cross sections. D-E. Ovary. F-G. Histochemical characterization of placentary obturator in the ovary. F. Lugol's. E and G. Aniline blue black. $\mathrm{ne}=$ nectary; $\mathrm{vb}=$ vascular bundle; ov = ovary; co = corolla; ob = obturator. Scale bars: $\mathrm{A}-\mathrm{C}, \mathrm{G}=20 \mu \mathrm{m} ; \mathrm{D}=$ $50 \mu \mathrm{m} ;$ and $\mathrm{F}-\mathrm{E}=10 \mu \mathrm{m}$. 
Fig. 6. A-E. Post-anthetic Condylocarpon isthmicum flower. F. Anthetic Condylocarpon isthmicum flower. A-B. Ovary in post-anthetic flower showing placentary obturator cells in secretory phase. B. Detail of placentary obturator cells. C. Longitudinal section of a portion of the style and ovary. D. Placentary obturator in the ovary, PAS reaction. E. Tetrad pollen grain is deflated and the base of style head has started to shrivel. F. Tetrad pollen grain germinating on the style head. $\mathrm{ov}=\mathrm{ovary} ; \mathrm{ob}=$ obturator; asterisk $=$ secretions; $\mathrm{tt}=$ transmission tissue; $\mathrm{pt}=$ pollen tube; $\mathrm{pg}=$ tetrad pollen grain. Scale bars: A-B $=20 \mu \mathrm{m} ; \mathrm{D}=50 \mu \mathrm{m}$. 

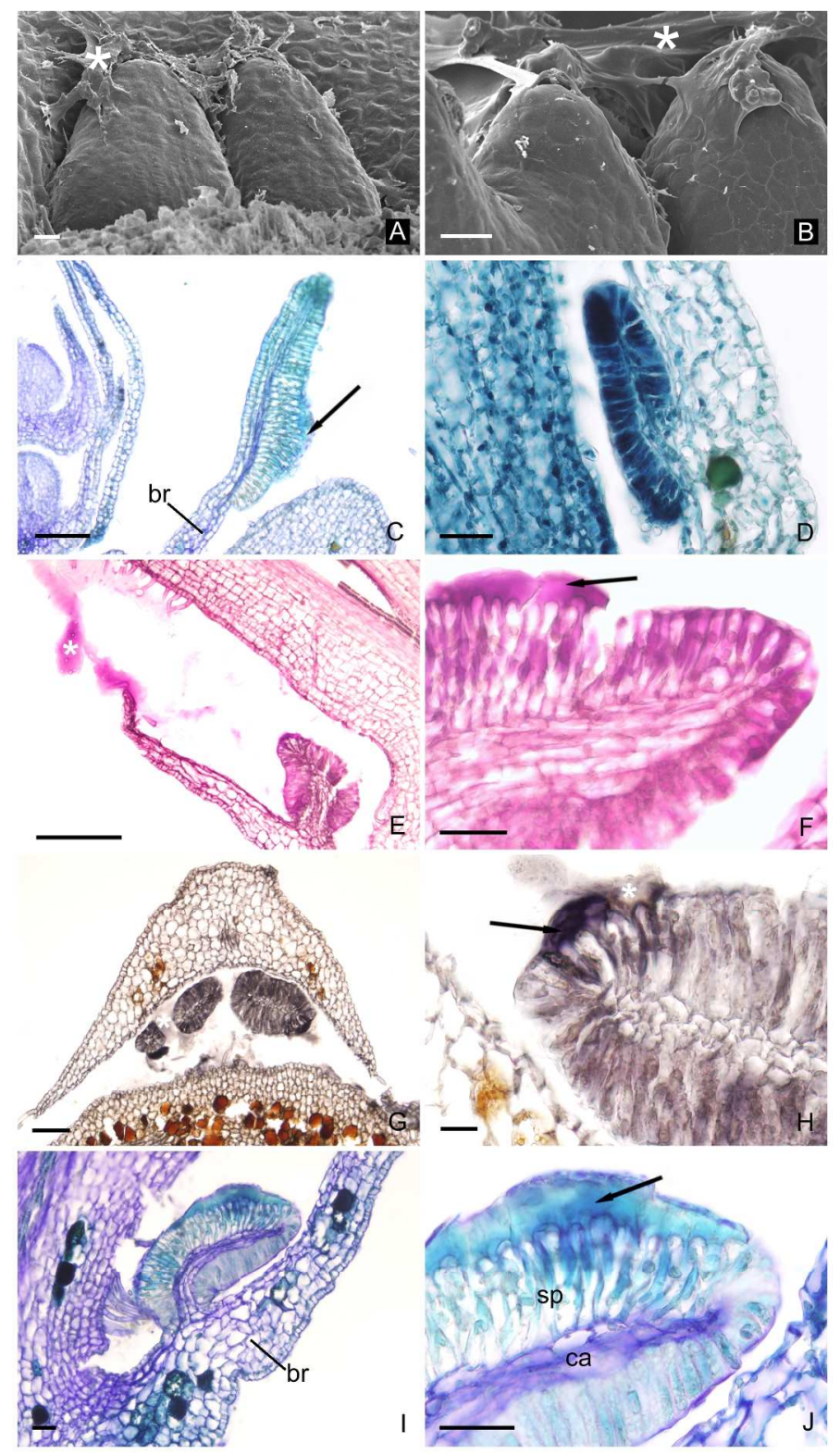

Fig. 1. Colleters of Condylocarpon isthmicum. A-B. SEM, colleters on the adaxial surface of bracts in a young inflorescence. C-J. Histochemical characterization of the exudate in the colleters. C. Nile blue. D. Aniline blue black. E-F. PAS reaction. G-H. Tannic acid-ferric chloride. I-J. Nile blue. Asterisk = extracellular secretion. Arrows $=$ Colleters at the secretory stage; note the cuticle displacement and subcuticular space. $\mathrm{br}=$ bracteole; $\mathrm{ca}=$ central axis formed by nonsecretory parenchyma cells; $\mathrm{sp}=$ secretory palisade epidermis. Scale bars: $A-F, H-J=20 \mu \mathrm{m} ; \mathrm{G}=50 \mu \mathrm{m}$. $160 \times 282 \mathrm{~mm}(300 \times 300 \mathrm{DPI})$ 


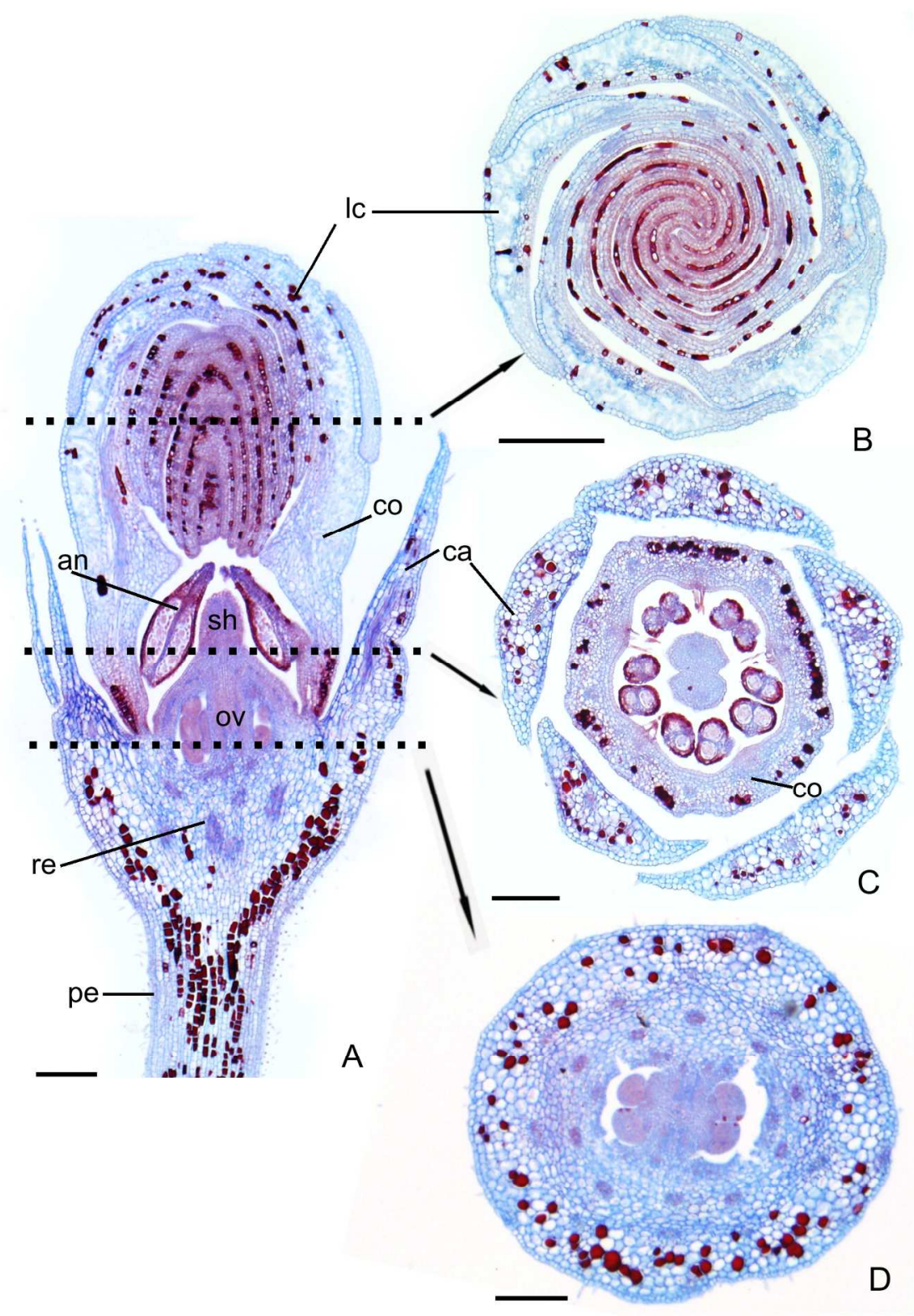

Fig. 2. Sections of the flower bud of Condylocarpon isthmicum. A. Longitudinal section. B-D. Cross sections; dotted lines indicate the position of the sections. an = anther; ca = calyx; co = corolla; lc =corolla lobes; pe $=$ pedicel; ov $=$ ovary; re $=$ receptacle; $s h=$ style head. Scale bars $=200 \mu \mathrm{m}$.

$160 \times 224 \mathrm{~mm}(300 \times 300$ DPI $)$ 


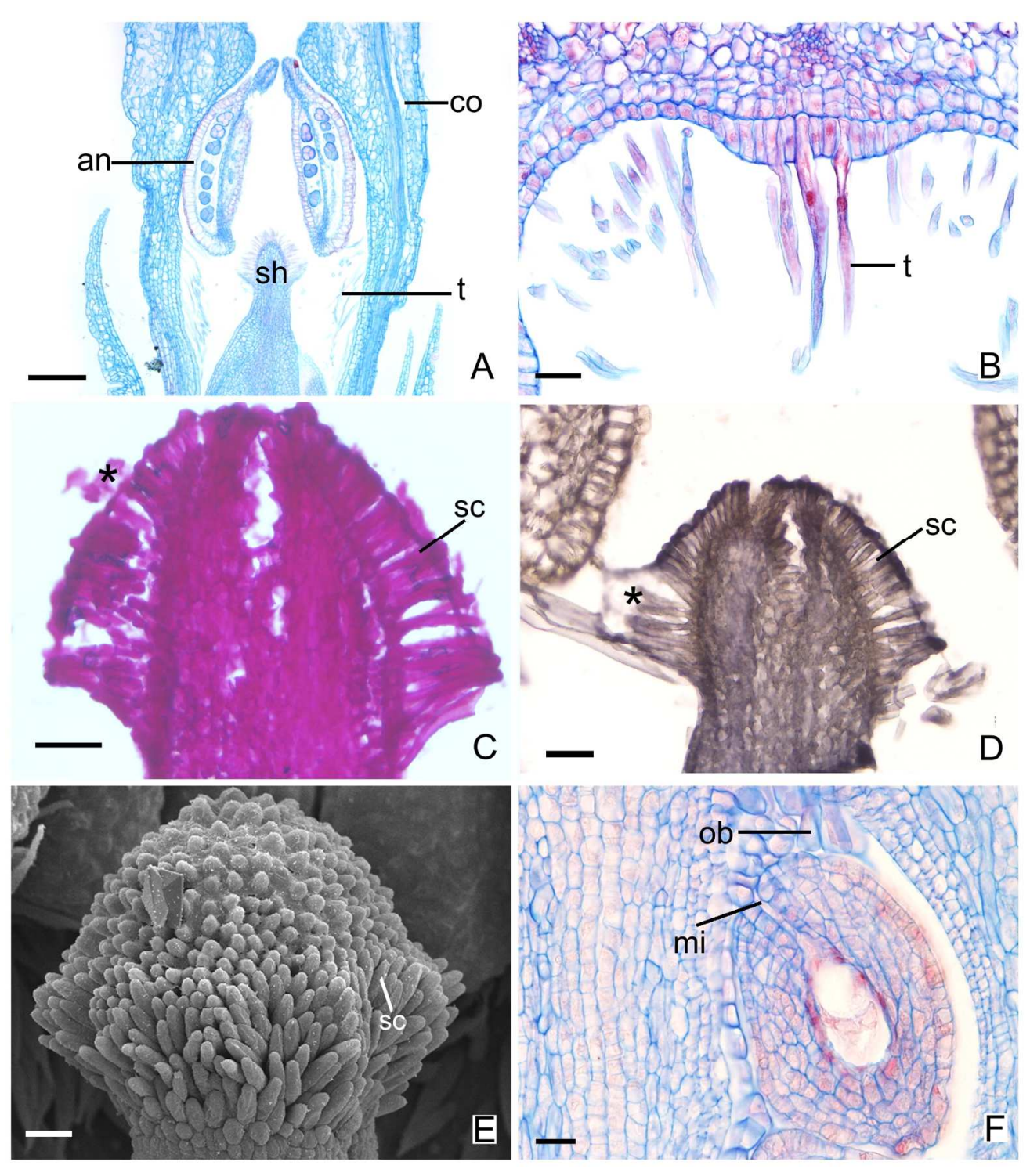

Fig. 3. Pre-anthetic Condylocarpon isthmicum flower. A. Longitudinal section, anthers positioned above the style head. B. Cross section, detail of trichome. C-D. Histochemical characterization of the style head. C. PAS reaction. D. Tannic acid-ferric chloride; note the extracellular secretion $\left(^{*}\right)$. E. SEM, style head covered by secretory epidermis. $\mathrm{F}$. Longitudinal section of ovary. asterisk $=$ secretion; $a n=$ anther; $c o=$ corolla; $t=$ trichomes; $\mathrm{sh}=$ style head; $\mathrm{sc}=$ secretory cell; ob = obturator; $\mathrm{mi}=$ micropyle. Scale bars: $\mathrm{A}=100 \mu \mathrm{m}$; and $\mathrm{B}-\mathrm{E}=20 \mu \mathrm{m}$. $160 \times 180 \mathrm{~mm}(300 \times 300 \mathrm{DPI})$ 


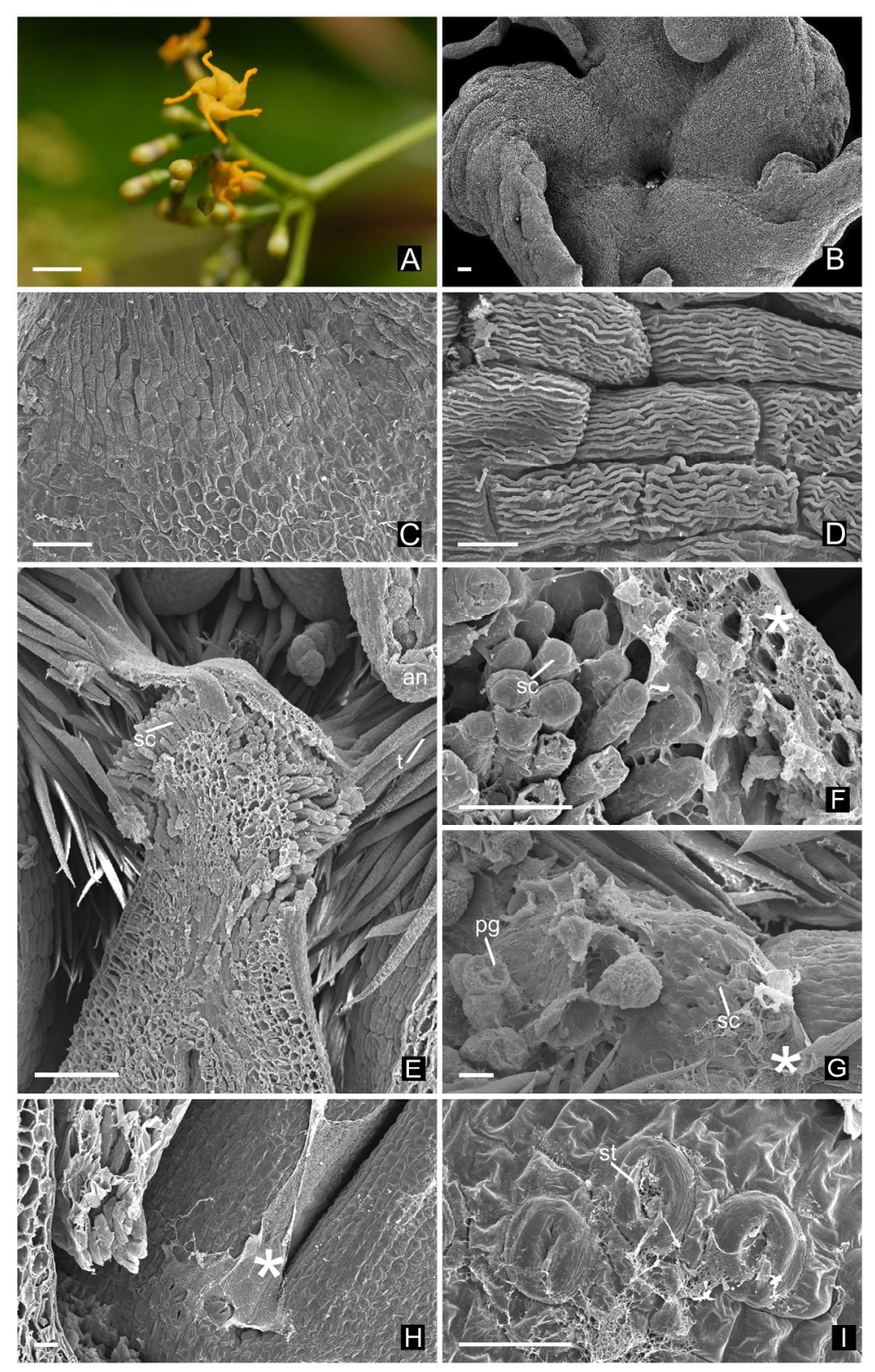

Fig. 4. Anthetic Condylocarpon isthmicum flower. A-B. Frontal view. C. Detail of adaxial epidermis of the lobes of the corolla near the aperture. D. Detail of ornamented cuticle. E. Style head covered by secretion.

F. Detail of style head secretory cells covered by secretion. G. Tetrad pollen grains on the style head secretory epidermis. H-I. Nectary at the base of the ovary. I. Detail of nectar-secreting stomata. asterisk = secretion; an = anther; $\mathrm{pg}=$ tetrad pollen grain; $\mathrm{sc}=$ secretory cell; st = stomata. Scale bars: $\mathrm{A}=2 \mathrm{~mm}$; $\mathrm{B}-\mathrm{C}, \mathrm{E}=100 \mu \mathrm{m} ; \mathrm{D}=10 \mu \mathrm{m}$; and F-I. $=20 \mu \mathrm{m}$. $160 \times 254 \mathrm{~mm}(300 \times 300 \mathrm{DPI})$ 

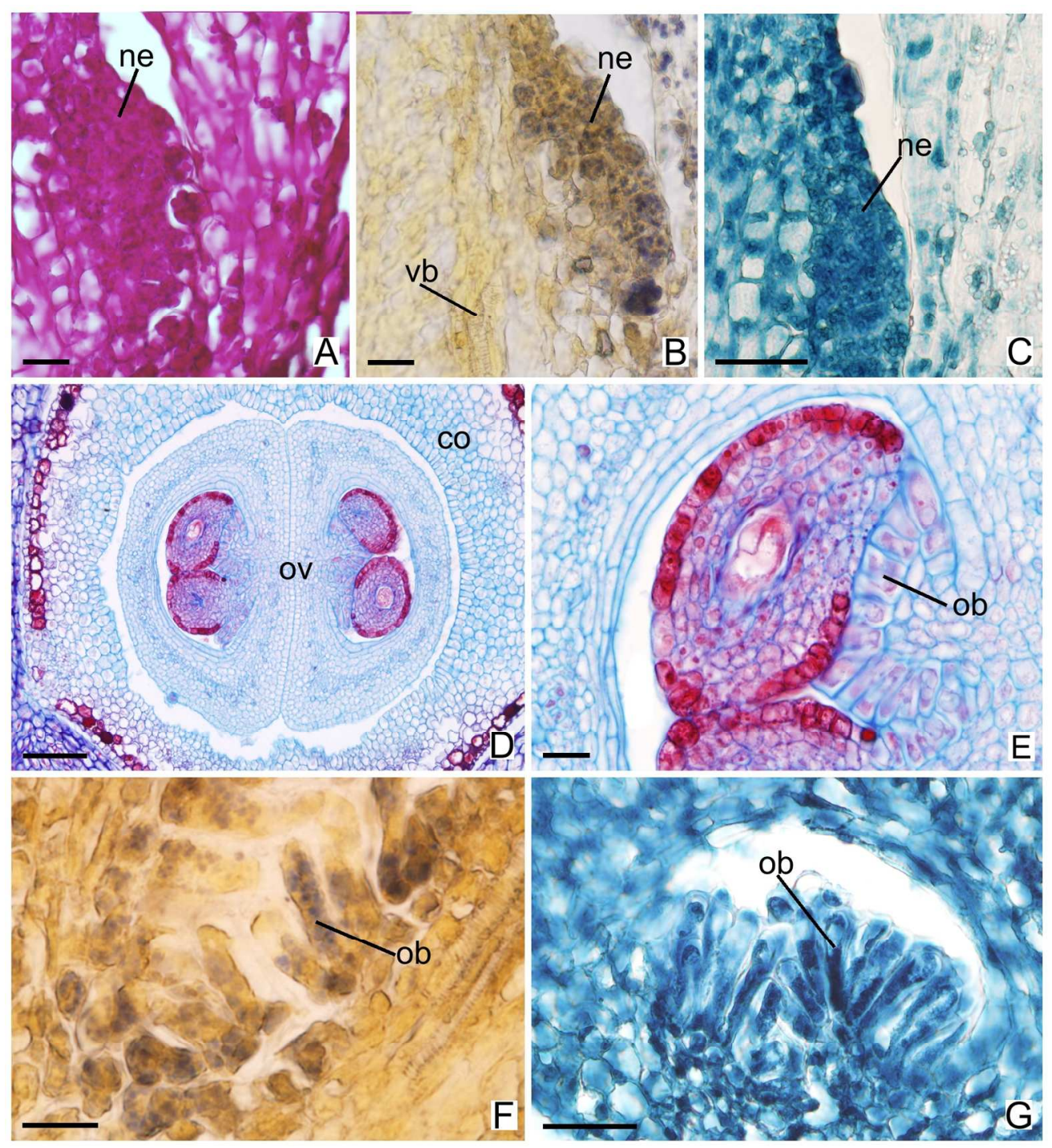

Fig. 5. Anthetic Condylocarpon isthmicum flower. A-C. Longitudinal sections. Histochemical characterization of the nectary at the base of the ovary. A. PAS reaction. B. Lugol's. C. Aniline blue black. D-G. Cross sections. D-E. Ovary. F-G. Histochemical characterization of placentary obturator in the ovary. F. Lugol's. E and $\mathrm{G}$. Aniline blue black. $\mathrm{ne}=$ nectary; $\mathrm{vb}=$ vascular bundle; ov = ovary; $c o=$ corolla; ob = obturator. Scale bars: $A-C, G=20 \mu \mathrm{m} ; \mathrm{D}=50 \mu \mathrm{m}$; and $\mathrm{F}-\mathrm{E}=10 \mu \mathrm{m}$. $160 \times 175 \mathrm{~mm}(300 \times 300 \mathrm{DPI})$ 

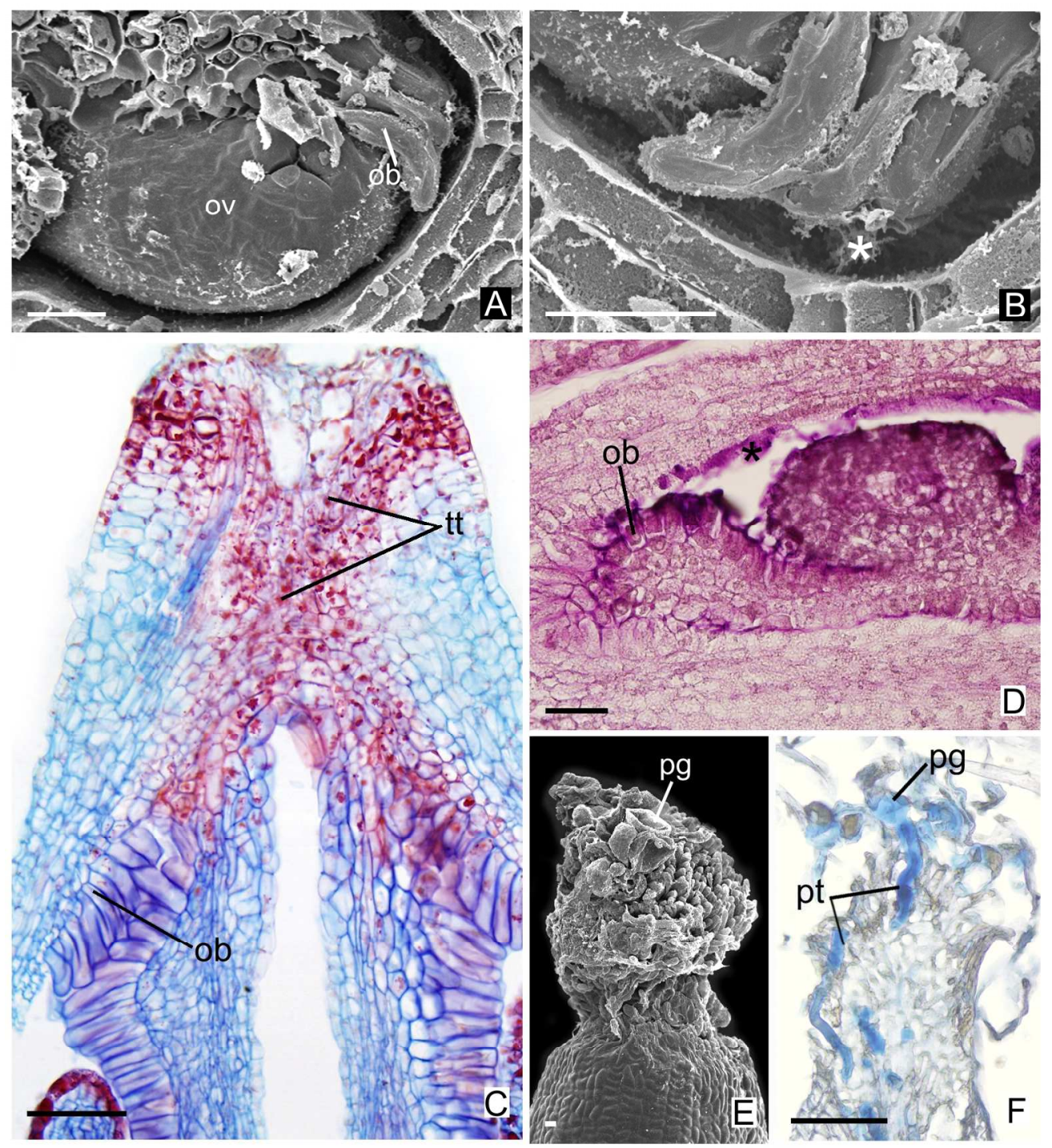

Fig. 6. A-E. Post-anthetic Condylocarpon isthmicum flower. F. Anthetic Condylocarpon isthmicum flower. AB. Ovary in post-anthetic flower showing placentary obturator cells in secretory phase. B. Detail of placentary obturator cells. C. Longitudinal section of a portion of the style and ovary. D. Placentary obturator in the ovary, PAS reaction. E. Tetrad pollen grain is deflated and the base of style head has started to shrivel. F. Tetrad pollen grain germinating on the style head. ov = ovary; ob = obturator; asterisk $=$ secretions; $\mathrm{tt}=$ transmission tissue; $\mathrm{pt}=$ pollen tube $\mathrm{pg}=$ tetrad pollen grain. Scale bars: $\mathrm{A}-\mathrm{B}=20 \mu \mathrm{m}$; $\mathrm{D}=50 \mu \mathrm{m}$.

$150 \times 165 \mathrm{~mm}(300 \times 300 \mathrm{DPI})$ 